\title{
Columnar Cell Variant of Papillary Thyroid Carcinoma: A Rare Case Report
}

Alae Eddine El Aissaoui*, Saad Benslimane, Tarik souiki, Ahmed Zerhouni, Imane Toughrai, Khalid Mazaz, Karim Ibn Majdoub

Visceral Surgery Service, Hassan II University Hospital, Faculty of Medicine and Pharmacy of Fez, Sidi Mohammed Ben Abdallah University, Fez, Morocco

DOI: $10.36347 /$ sjmcr.2021.v09i02.001

| Received: 19.01.2021 | Accepted: 01.02.2021 | Published: 03.02.2021

*Corresponding author: Alae Eddine El Aissaoui

\section{Abstract}

The columnar cell variant is a rare subtype of papillar thyroid carcinomas (PTC), characterized by its morphologic features and aggressive biologic course. Its diagnosis depends on the postoperative histological study of the surgical piece and its prognosis remains controversial. The treatment is mainly surgical while post-operative radio iodine therapy has proven its worth. We repot the case of a 73 years old patient, with history of arterial hypertension, having presented during a medical checkup a cervical painless swelling that was mobile on swallowing, and the lymph node areas were free. The thyroid laboratory tests were normal. The ultrasound cervical examination found a hetero multi nodular goiter classified TIRADS III. The patient has undergone a total thyroidectomy. The anatomopathological study of the surgical piece revealed a papillary carcinoma of the right lobe of the thyroid in its cylindrical cells variant measuring approximately $4 \mathrm{~mm}$, located in contact with the thyroid capsule which it invades focally with presence of a single neoplastic embolus. Postoperative recovery was marked by transient hypocalcemia that was controlled by calcium supplementation and the patient was discharged from hospital 5 days later. The patient received 131-Iodine therapy $(3.7 \mathrm{GBq})$ followed by post therapy whole body scans 6 days and 6 months later that didn't show any pathological focus. The columnar cell variant of papillary thyroid carcinomas represents an aggressive variant of PTC potentially portending and unfavorable prognosis. The encapsulated form or small tumors demonstrates a more favorable outcome with indolent clinical process, which shows relatively slow growth and low incidence of recurrence or metastasis. The surgery still remains the main treatment while the post-operative radio iodine therapy plays an important role allowing the sterilization of tumor residues and thus reduces the rate of recurrence.

Keywords: Columnar Papillary Thyroid Carcinoma.

Copyright $(\mathcal{C} 2021$ The Author(s): This is an open-access article distributed under the terms of the Creative Commons Attribution 4.0 International License (CC BY-NC 4.0) which permits unrestricted use, distribution, and reproduction in any medium for non-commercial use provided the original author and source are credited.

\section{INTRODUCTION}

Papillary thyroid carcinomas are the most common form of thyroid cancers. Generally, of good prognosis, they present various clinical and evolutionary aspects according to their origin.

The columnar cell variant of papillary thyroid carcinoma (CCVPTC) is a rarer variant with a more reserved prognosis.

We report the case of a patient who presented a columnar cell variant of papillary thyroid carcinoma discovered in the anatomopathological study of the surgical piece.

\section{CASE RePORT}

73-year-old patient with history of arterial hypertension under treatment has presented during a medical check-up a cervical swelling justifying the realization of a cervical ultrasound then referred to our facility for medical care.

The cervical examination found a patient with a painless cervical swelling that was mobile on swallowing. The lymph node areas were free and the rest of the clinical examination was without abnormalities.

The thyroid laboratory tests were normal. A cervical ultrasound examination found a hetero multi nodular goiter; the largest nodule being on the left lobe measuring $3.5 \mathrm{~cm}$ classified TIRADS III.

The patient has undergone a total thyroidectomy. The anatomopathological study of the surgical piece revealed a papillary carcinoma of the right lobe of the thyroid in its cylindrical cells variant 
measuring approximately $4 \mathrm{~mm}$, located in contact with the thyroid capsule which it invades focally with the presence of a single neoplasic embolus.

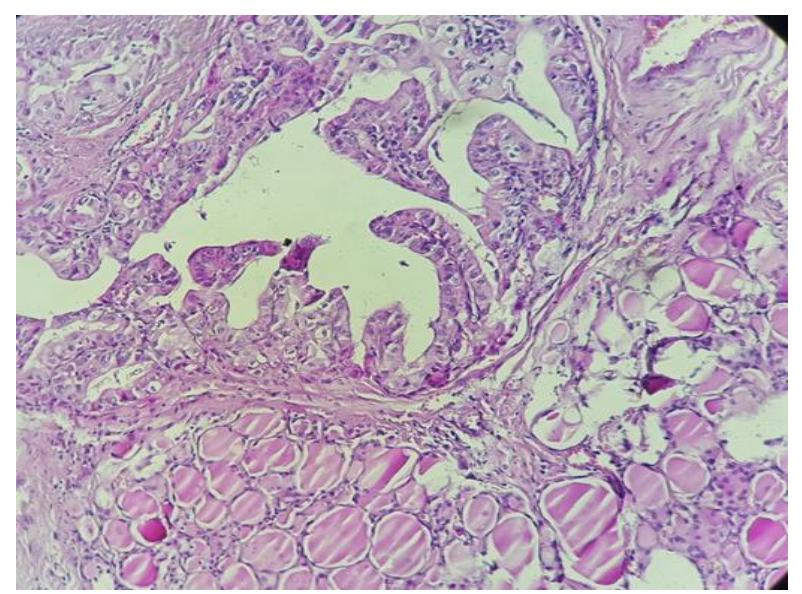

Fig-1: Proliferation with papillary projections in a thyroid parenchyma site

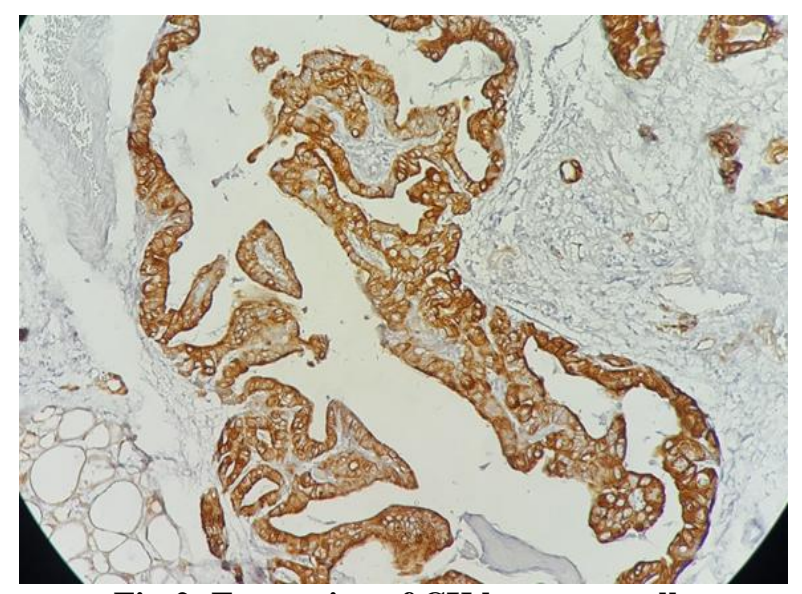

Fig-2: Expression of CK by tumor cells

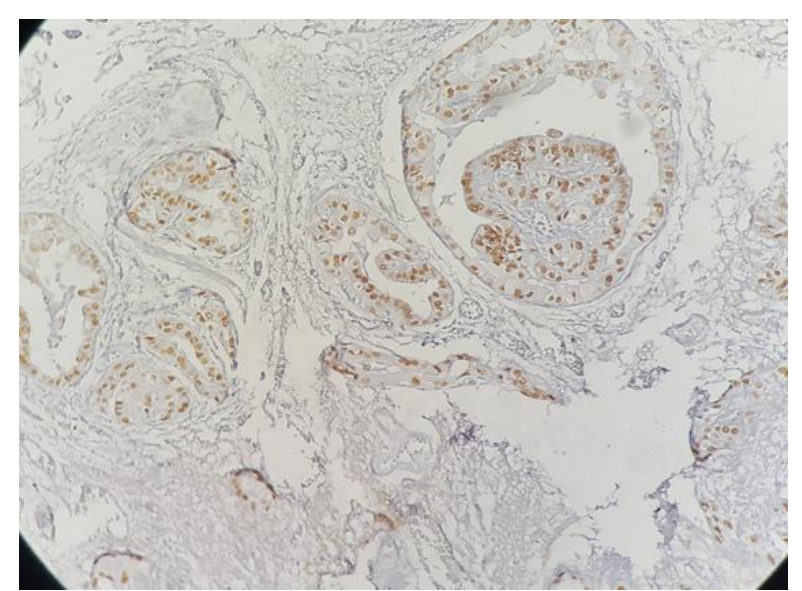

Fig-3: Expression of TTF1 by tumor cells

Postoperative recovery was marked by transient hypocalcaemia that was controlled by calcium supplementation.
The patient was discharged from hospital 5 days later. The decision of the multidisciplinary concertation meeting was Radioactive Iodine therapy.

The patient received 131-Iodine therapy (3.7 $\mathrm{GBq})$. The post-therapy whole body scan was performed 6 days later, revealing the presence of a thyroid remnant without distant pathological focus with low level of thyroglobulin.

The patient was put on L-thyroxine-based hormonal braking treatment. An efficacy assessment was carried out 6 months later, the whole body scan didn't show any pathological distant focus and the patient was declared cured.

\section{DISCUSSION}

Papillary thyroid carcinoma is the most common malignancy in the thyroid gland, which accounts for $90 \%$ of all thyroid cancers [1, 2]. It is considered an indolent malignant tumor with an overall mortality rate of $1 \%$ per year [3].

The World Health Organization classification of thyroid tumors recognizes a subcategory of thyroid papillary carcinoma termed the biologically aggressive variants that include the diffuse sclerosing variant, the tall cell variant, and the columnar cell variant [4].

The columnar cell variant of papillary thyroid carcinoma (CCVPTC) is a rare subtype, which accounts for $0.15-0.2 \%$ of all PTCs [5].

Studies showed that CCVPTC has a fast growth rate and a high incidence of recurrence, and this type of tumors is associated with local invasion and early lymph node metastasis [6-8]. However, the prognosis of CCVPTC remains controversial, because the encapsulated form has a more favorable outcome with indolent clinical process, which shows relatively slow growth and low incidence of recurrence or metastasis [9-11].

The presence or absence of extrathyroidal invasion represents the most important parameter in predicting the behavior of these tumors. Tumors confined to the thyroid gland are associated with an excellent prognosis and can be managed conservatively (less than total thyroidectomy with or without radioactive iodine therapy) whereas tumors that invade beyond the thyroid capsule with extension into perithyroidal soft tissues behave more aggressively, necessitating more aggressive management (total thyroidectomy with supplemental radioactive iodine therapy) and evaluation for disseminated visceral disease [12].

Ultrasonography may show hypoechoic nodules with or without calcifications and with at least more than one typical malignant sonographic feature [13]. 
Alae Eddine El Aissaoui et al., Sch J Med Case Rep, Feb, 2021; 9(2): 116-119

The diagnosis of columnar-cell carcinoma largely depends on the postoperative pathologic findings:

The accurate diagnosis of CCVPTC is difficult upon FNA (fine needle aspiration) cytology, because the tumor cells in CCVPTC lack the nuclear features of the classic pattern of papillary carcinoma, which shows nuclear grooving and intranuclear pseudo-inclusions $[14,15]$. Based on histology, CCVPTC is defined as papillae or gland-like structures lined by columnar cells that have prominent nuclear stratification [16].

Because the nuclear features of PTC are not well represented in the $\mathrm{CCV}$, these tumors may be mistaken for metastatic intestinal, endometrial, or pulmonary adenocarcinomas, from which they can be distinguished because of immunohistochemical positivity for both thyroglobulin and thyroid transcription factor 1 (TTF-1). To the best of our knowledge, there is no clear consensus regarding the minimal percentage of columnar cells that confers a diagnosis of PTCCCV, with reported cases varying from $30 \%$ to $80 \%$ [17-19].

The management of CCV is controversial, and the current guidelines of the American Thyroid Association recommend total thyroidectomy or near total thyroidectomy and lobectomy, central lymphadenectomy, and postoperative RAI (radioactive iodine) as indicated [20], the rates of definitive hypoparathyroidism and recurrent laryngeal nerve injury following total thyroidectomy and total thyroidectomy associated with routine central lymph node dissection were higher than that after lobectomy and total thyroidectomy $[21,22]$.

External-Beam Radiation Therapy (EBRT) is typically reserved as a last resort after surgery and RAI have been attempted [25]. Some studies revealed that EBRT has been traditionally used to treat incompletely resected tumors, unresectable diseases, aggressive variants, and to reduce the risk of locoregional recurrence $[23,24]$.

\section{Conclusion}

The thyroid papillary carcinoma of columnar cell type is a distinct morphologic type of thyroid papillary carcinoma.

The biologic behavior of this tumor is predicated on clinical stage, with the presence or absence of extrathyroidal invasion being the single most important parameter.

The most useful features in the differentiation of CCVPTC from other PTC are the presence of columnar cells. Treatment for columnar-cell carcinoma of the thyroid is mainly surgical resection.
Due to the frequent recurrences and metastases, the prognosis for unencapsulated columnarcell carcinoma is poor, whereas the encapsulated columnar-cell variety has been reported to have a favorable prognosis.

A post-operative treatment with radioactive Iodine 131 allows to irradiate any persistent neoplastic focus decreasing the risk of subsequent recurrence, eradicate normal thyroid remnants and to perform a post therapy whole body scan to detect metastatic disease.

\section{REFERENCES}

1. Hundahl SA, Fleming ID, Fremgen AM, Menck HR. A National Cancer Data Base report on 53,856 cases of thyroid carcinoma treated in the US, 1985- 1995. Cancer: Interdisciplinary International Journal of the American Cancer Society. 1998 Dec 15;83(12):2638-48.

2. Papp S, Asa SL. When thyroid carcinoma goes bad: amorphological and molecular analysis. Head NeckPathol. 2015;9:16-23

3. Rosai J, Carcangiu ML, DeLellis RA. Tumors of the thyroid gland. In: Rosai J, Sobin LE, editors. Atlas of tumor pathology Institute of Pathology, 1992. Third series. Fascicle 5. Washington, DC: Armed Forces

4. Hedinger C, Williams ED, Sobin LH. Histological typing of thyroid tumours. In: World Health Organization classifica tion of tumours. Berlin: Springer-Verlag. 1988:9-11.

5. Sywak M, Pasieka JL, Ogilvie T. A review of thyroid cancerwith intermediate differentiation. J Surg Oncol. 2004;86:44-54

6. Berends D, Mouthaan PJ. Columnar-cell carcinoma of thethyroid. Histopathology. 1992;20:360-362

7. Evans HL. Columnar-cell carcinoma of the thyroid. A report oftwo cases of an aggressive variant of thyroid carcinoma. Am JClin Pathol. 1986;85:7780

8. Gaertner EM, Davidson M, Wenig BM. The columnar cell variantof thyroid papillary carcinoma. Case report and discussion ofan unusually aggressive thyroid papillary carcinoma. Am JSurg Pathol. 1995;19:940-947

9. Evans HL. Encapsulated columnar-cell neoplasms of thethyroid. A report of four cases suggesting a favorableprognosis. Am J Surg Pathol. 1996;20:1205-1211

10. Ferreiro JA, Hay ID, Lloyd RV. Columnar cell carcinoma ofthe thyroid: report of three additional cases. Hum Pathol. 1996;27:1156-1160

11. Wenig BM, Thompson LD, Adair CF, Shmookler B, Heffess CS. Thyroid papillary carcinoma of columnar cell type: aclinicopathologic study of 16 cases. Cancer. 1998;82:740-753

12. Wenig BM, Thompson LD, Adair CF, Shmookler B, Heffess CS. Thyroid papillary carcinoma of columnar cell type: a clinicopathologic study of 16 cases. Cancer: Interdisciplinary International 
Journal of the American Cancer Society. 1998 Feb $15 ; 82(4): 740-53$.

13. Shin JH. Ultrasonographic imaging of papillary thyroidcarcinoma variants. Ultrasonography. 2017;36:103-110

14. Verma R, Paul P. Columnar cell variant of papillary thyroidcarcinoma: a diagnostic dilemma in fine-needle aspirationcytology. Diagn Cytopathol. 2016;44:816-819

15. Ylagan LR, Dehner LP, Huettner PC, Lu D. Columnar cellvariant of papillary thyroid carcinoma. Report of case withcytologic findings. Acta Cytol. 2004;48:73-77

16. Bongiovanni M, Mermod M, Canberk S, Saglietti C, Sykiotis GP, Pusztaszeri M, Ragazzi M, Mazzucchelli L, Giovanella L, Piana S. Columnar cell variant of papillary thyroid carcinoma: cytomorphological characteristics of 11 cases with histological correlation and literature review. Cancer cytopathology. 2017 Jun;125(6):389-97.

17. Wenig BM, Thompson LD, Adair CF, Shmookler B, Heffess CS. Thyroid papillary carcinoma of columnar cell type: a clinicopathologicstudy of 16 cases. Cancer. 1998; 82:740-753.

18. Silver CE, Owen RP, Rodrigo JP, Rinaldo A, Devaney KO, Ferlito A. Aggressive variants of papillary thyroid carcinoma. Head Neck.2011; 33:1052-1059.

19. Ferreiro JA, Hay ID, Lloyd RV. Columnar cell carcinoma of the thyroid: report of three additional cases. Hum Pathol. 1996; 27:1156-1160.
20. Cooper DS, Doherty GM, Haugen BR, Kloos RT, Lee SL, Mandel SJ, Mazzaferri EL, McIver B, Sherman SI, Tuttle RM. Management guidelines for patients with thyroid nodules and differentiated thyroid cancer: The American Thyroid Association Guidelines Taskforce. Thyroid. 2006 Feb 1;16(2):109-42.

21. Conzo G, Avenia N, Ansaldo GL, Calò P, De Palma M, Dobrinja C, Docimo G, Gambardella C, Grasso M, Lombardi CP, Pelizzo MR. Surgical treatment of thyroid follicular neoplasms: results of a retrospective analysis of a large clinical series. Endocrine. 2017 Feb 1;55(2):530-8.

22. Gambardella C, Tartaglia E, Nunziata A, Izzo G, Siciliano G, Cavallo F, Mauriello C, Napolitano S, Thomas G, Testa D, Rossetti G. Clinical significance of prophylactic central compartment neck dissection in the treatment of clinically nodenegative papillary thyroid cancer patients. World journal of surgical oncology. 2016 Dec;14(1):1-5.

23. Nixon IJ, Simo R, Newbold K, Rinaldo A, Suarez C, Kowalski LP, Silver C, Shah JP, Ferlito A. Management of invasive differentiated thyroid cancer. Thyroid. 2016 Sep 1;26(9):1156-66.

24. Fussey JM, Crunkhorn R, Tedla M, Weickert MO, Mehanna H. Externalbeam radiotherapy in differentiated thyroid carcinoma: a systematicreview. Head Neck. 2016;38 (Suppl 1):E2297-E2305.

25. Schneider DF, Chen H. New developments in the diagnosis and treatmentof thyroid cancer. CA Cancer J Clin. 2013;63(6):374-394. 